\title{
Depois do Leviathan
}

After the Leviathan

\section{António Manuel Hespanha}

Professor na Faculdade de Direito da Universidade Nova de Lisboa

\section{Resumo}

0 Autor faz o balanço das duas últimas décadas da historiografia institucional da época moderna, verificando até que ponto subsistem hoje os pontos de vista inovadores nos anos 70 sobre uma matriz pluralista e compósita das unidades políticas europeias. Reagindo a posições recentes da historiadora Laura de Mello e Souza (USP) defende que essa matriz política, identificada inicialmente pata a Europa, pode ser estendida à análise política das sociedades coloniais, valorizando - como o vem fazendo largamente a última historiografia do mundo colonial ibérico - a vitalidade política das periferias, bem como a equivosicade e multi-direccionalidade das relações entre a metrópole e as colónias.

\section{Abstract}

The Author sketches an assessment of the last two decades of constitutional history of the early modern period, checking the current sustainability of the approach on which was based the innovative historiography of the '70s, which stood for the plurality and composite nature of the "corporative" polities. Reacting to a recent book of the Brazilian historian Laura de Mello e Souza (USP), he argues that such a pluralistic and decentralized political model shall also be applied to the colonial societies; the resulting being the emphasizing of local political agency and the multi-leveled and entangled pattern of governance of the so-called "colonial Empires", a topic on which the most recent colonial historiography is conveying.

\section{Palavras-chave}

Estado / formas de governo, centralismo, Império português, história política

\section{Keywords}

State / forms of government, centralism, Portuguese Empire, political history 
HESPANHA, António Manuel. As vésperas do Leviathan: Instituições e poder político Portugal, séc. XVII. Coimbra: Almedina, 1994; antes, fora publicado, numa forma mais abreviada, por Taurus Ediciones, de Madrid, 1989.
Há cerca de vinte anos, defendi, numa tese de doutoramento, uma visão inusitada da organização do poder na sociedade de Antigo Regime, com especial aplicação à situação portuguesa dos meados do séc. XVII. 0 livro - depois publicado, em 1994, numa edição impressa 1, algo alterada e bastante amputada de anexos muito volumosos - baseava-se numa lista dos oficiais do reino, elaborada c. 1632, e no que a doutrina jurídica da época dizia acerca do poder e da sua organização. Nesse sentido, era um livro muito assente em fontes; só que lidas de uma maneira nova e, a meu ver, mais liberta de imagens translatícias, que só tinham deformado o entendimento do sistema político daquilo a que passei a chamar as "monarquias corporativas" dos sécs. XVI a meados de XVIII. As quais, segundo creio, constituem o tipo ideal das unidades políticas do primeiro Antigo Regime, nomeadamente (e até mais tarde) na Europa Católica.

Entretanto, muita água correu. Mas, do ponto do que então escrevi, não correu tanta assim. Quando o livro saiu, ele representava uma interpretação francamente minoritária - embora não isolada nem órfã - do sistema político que, por facilidade, designarei, para já, de corporativo:

* legitimação da constituição da polis na natureza e na tradição,

* pluralismo político e, logo, normativo;

* redução das funções da coroa a uma administração passiva ("0 melhor, Senhora, é não obrar", recomendavam, receosos, os Conselheiros de Estado à novel regente D. Luísa de Gusmão, variável, como as mulheres, determinada como as espanholas e voluntarista como uma Guzmán ...), que se limitasse a fazer justiça, preservando os direitos adquiridos (Rechtsbewährungsstaat);

* e, decorrendo disto, a centralidade de um direito, garante desses direitos, decalcado das várias leis que o mundo conhecia - a lei divina, a lei da natureza externa das sociedades, mas também da lei interna das almas dos homens, tanto a natureza das instituições, como a geometria da lama dos homens, a tradição feita lei, o exemplo que fez fama (façanha), o estilo processual que amolda a prática dos tribunais, tudo isto posto em ordem, para os casos notáveis, por esse saber prático (praticável) dos jurisconsultos a que se chamava prudentia, prudentia iuris, jurisprudência, que estes, nos seus pesados livros e nas suas sopesadas decisões, deviam ensinar (doctrina).

Esta insistência no papel conformador do direito já o salientara Abraão Gurevic, quando se referiu à sociedade medieval como uma "sociedade construída sobre o direito". Ao passo que esta natureza não legislativa, mas prudencial do direito, foi depois magistralmente descrita por Z. Baumann no seu belo livro Legislators and interpreters. Mas nunca é demais esclarecer o que é que se quer dizer com isto de centralidade do direito, de tal modo o tema aparece obscuro para muitos leitores. De novo, uma questão de anacronismo. Hoje, quando falamos de centralidade do direito, entendemos que se fala no "primado da lei", na ideia - que é muito comum entre os juristas - de que o mundo é um grande código e que, para conhecer o mundo, basta conhecer os códigos. Os antigos também diziam "quod non est in libris (in actis), non est in mundo" [o que não está nos livros (nos processos) não está no mundo]. Só que os livros de que eles falavam não eram os códigos de leis; eram os livros de doutrina juridica, aquilo a que 
Como seria o meu caso, segundo alguma interpretação.

LOMBARDI, Luigi. Saggio sul diritto giurisprudenziale. Milano: Giuffrè Ed., 1975; em sintese, no meu livro Cultura jurídica europeia. Síntese de um Milénio. Florianopolis: Fundação Boiteux, 2005, max. 5.3 e 5.6; com aplicação ao ambiente colonial americano, ANZOATEGUI, Victor

Tau. Casuismo y sistema. Buenos Aires: Inst. De Invest. de Historia del Derecho, 1992; BENTON, Lauren.The Legal Regime of the South Atlantic World, 1400-1750: Jurisdictional Complexity as Institutional Order.Journal of World History, 11.1 (2000). p. 27-56; bem como o meu artigo, aplicado ao Brasil, "Porque é que existe e em que é que consiste um direito colonial brasileiro: Quaderni fiorentini per la storia del pensiero giuridico moderno, Firenze, 2006.

\section{4}

SOUZA, Laura de Mello e. 0 sol e a sombra: política e administração na América portuguesa do séc. XVIII. São Paulo: Companhia das Letras, 2006. p.55 (sobre uma "segunda ordem de problemas" que os meus pontos de vista têm que enfrentar).

5

Ver, antes, nota 3

Uma resenha da tradição que este meu livro desencadeou pode ser acompanhada a partir dos seguintes trabalhos: R. Rowland. lus commune, 1990, pp.433-435; B. Clavero.The Journal of Modern History. 63.4, 1991, pp. 801-802; C. A. Hanson, The American Historical Review, 97.1 1992, pp.221-222; Julius Kirchner, The Journal of Modern History, 67, 1995, pp.758-759; Latin American Review, 31.1, 1996, pp.113-134; Jean Frédéric Schaub, Ann. Economies. Sociétés. Civilisations., 46.2, mars-avril1991 „pp.502-505. Comentários: Jean-Frédéric Schaub, "La penisola iberica nei secoli XVI e XVII: la questione dello Stato", Studi Storici, anno 36, gennaiomarzo 1995; Idem, "L'histoire politique sans l'état: mutations et reformulations", Historia a debate, III, Santiago de Compostela: 1993, pp.217-235; Idem, "Le temps et l'État: vers un nouveau régime historiographique de l'ancien régime français", Quaderni Fiorentini per la Storia del Pensiero Giuridico Moderno, 25, 1996, pp.127-182;Angelo Torre, "Percorsi della pratica. 1966-1995", Studi storici, 1995, pp.799-829 (mais critico); Roberto Bizzochi, "Storia debile, storia forte", Storica, 1996, pp.93-114. então se chamava o "direito comum" (ius commune). Por um lado, estes livros, que já tinham muito pouco a ver com os textos de direito romano ou canónico, a bem dizer não tinham nada a ver com as leis do reino. Daí que, ainda que algum historiador (do direito) ande obcecado com o direito 2 , não liga quase nada às leis dos reis, embora possa ligar muito à doutrina dos juristas e à jurisprudência dos tribunais. Por outro lado, ligando muito a esta doutrina e a esta jurisprudência, ele tem que estar a ligar também muito ao direito praticado, ao direito vivido, aos arranjos da vida. É que uma das características do direito comum era a sua enorme flexibilidade, traduzida no facto de o direito local se impor ao direito geral e de, na prática, as particularidades de cada caso - e não as regras abstractas - decidirem da solução jurídica. Isso quer dizer que a centralidade do direito se traduzia, de facto, na centralidade dos poderes normativos locais, formais ou informais, dos usos das terras, das situações "enraizadas" (iura radicata"), na atenção às particularidades de caso; e, em resumo, na decisão das questões segundo as sensibilidades jurídicas locais, por muito longe que andassem daquilo que estava estabelecido nas leis formais do reino. Por fim, esta mesma flexibilidade do direito, engendrava uma possibilidade infinita de recursos, bem como a possibilidade de paralisar um comando, uma ordem, uma norma oficial, durante anos a fio, somando apelações a agravos, recursos eclesiásticos a recursos civis, súplicas ao rei (ao vice-rei, ao Conselho Ultramarino) aos mais variados embargos e medidas cautelares. Esta função "desreguladora" e "paralizante" do direito é imediatamente evidente a quem tiver trabalhado um pouquinho que seja com o direito desta época ${ }^{3}$. Mas, para quem não passou por aí, direito significa antes imposição, cogência, execução, inflexibilidade, formalismo. Com isto, fecho o parênteses sobre o direito, esperando ter explicado porque é que, nas minhas análises, não me deixo "magnetizar pelo mundo dos juristas e dos teólogos [...] esquecendo que a lei muitas vezes permanecia letra morta" 4 . É que, neste mundo do direito prático doutrinal, a lei também permanecia, quase sempre, letra morta, em face das situações criadas pelas práticas locais ${ }^{5}$. De facto, como escreveu Alexis Tocqueville, também citado pela prestigiada historiadora, "Quem quisesse julgar o governo daquele [do Antigo Regime] tempo pelo conjunto das leis incorreria nos erros mais ridículos". Mas o mesmo acontece a quem, para esse mundo, confunda direito com lei... Prossigo com aspectos mais gerais.

À medida que estudos de detalhe iam sendo feitos, as ideias propostas foram ganhando um favor crescente, pelo menos para as monarquias e principados da Europa Sud-0cidental ${ }^{6}$. Porém, estes pontos de vista bastante singulares, mesmo apenas para as periferias meridionais da Europa, tiveram que se defrontar com um ambiente desconfiado e até hostil, porque abalavam muitas visões estabelecidas, algumas delas subsidiárias de compreensões mais vastas dos historiadores, que tinham que ver com as suas posições políticas, ideológicas, existenciais, no mundo que viviamos; outras, pura e simplesmente, herdeiras da historiografia liberal que, para marcar mais a ruptura da Revolução, carregava de cores sombriamente monocêntricas e opressoras qualquer das sociedades anteriores. Nunca me incomodou muito estar em contra-mão, nem fiz grandes esforços para provar ansiosamente que tinha razão, se é que estas coisas da história têm mais do que apenas feixes embrulhados de razões. Sendo certo que cada dia encontrava pequenos indícios de que não dissera disparates enormes, também tinha a certeza de que a "realidade histórica" era muito facetada 
Citado no meu trabalho Da 'iustitia' à 'disciplina'. Textos, poder e política penal no Antigo Regime. Anuario de história del derecho español, Madrid: 1988; versão portuguesa, Estudos em homenagem do Prof. Eduardo Correia, Coimbra: Faculdade de Direito de Coimbra, 1989; versão francesa, Le projet de Code pénal portugais de 1786. Un essai d'analyse structurelle, La Leopoldina. Le poltiche criminali nel XVIII secolo, vol. 11, Milano: Giuffrè, 1990, pp.387-447. Versão resumida em F. Tomás y Valiente et al., Sexo barroco y otras transgresiones premodernas, Madrid: Alianza, 1990, pp.175-186. A informação foi colhida de MELO, Francisco Freire de, Discurso sobre os delitos e as penas e qual foi a sua proporção nas differentes épocas da nossa jurisprudencia. Lisboa: 1816, p.9.

THOMAZ, Luis Filipe. A estrutura política e administrativa do Estado da India no séc. XVI. In:_____ De Ceuta a Timor. Lisboa: Difel, 1994 (1a ed. 1985)

9

Recorrendo a uma imagem de António Vieira recentemente recordada por Laura de Melo e Souza na sua citada obra. e complexa; mas que o era ainda mais o que os historiadores, falando cada um a partir de sensibilidades particulares e lugares culturais e institucionais diferentes, contavam acerca dela.

Eu próprio fui testando extensões. A primeira decorreu do desafio de um malogrado grande amigo que, tendo salientado num seu livro, já clássico, a dureza do direito penal de Antigo Regime, me provocou a demonstrar que, também na punição, o direito das monarquias corporativas era assim tão pouco interventivo. 0 bom senso indicava que tinha que o ser. Bastava ler a interminável lista de crimes capitais do Livro $V$ da Ordenações - compreendendo até a masturbação ... - para pensar, como o pensou Frederico II quando, durante a preparação do Allgemeines Landrecht, tho terão lido: "Mas ainda haverá gente viva neste país ?". Como o recurso ao (nosso) bom senso, em história, é muito perigoso, socorri-me de fontes fiáveis e lá pude documentar que, pelo menos em Portugal, a pena de morte era rarissimamente executada. Porventura porque, como cantou Chico Buarque no Fado tropical, " Todos nós herdamos no sangue lusitano uma boa dose de lirismo (além da sífilis, é claro) Mesmo quando as minhas mãos estão ocupadas em torturar, esganar, trucidar Meu coração fecha os olhos e sinceramente chora..."; ou, mais exactamente - porque, nisto de história, acredito tão pouco [como o poeta, de resto ...] no espírito dos povos, como no espírito das suas historiografias -, porque as leis não eram feitas para aplicar estritamente. Como terá escrito Alexandre de Gusmão, a mando do rei, a Inácio da Costa Quintela, um feroz juiz da Relação do Porto. "Sua Majestade manda advertir Vossa Mercê, que as leis são feitas com muito vagar e sossego, e nunca devem ser executadas com aceleração [...] porque o legislador é mais empenhado na conservação dos Vassalos do que no castigo da Justiça, e não quer que os ministros procurem achar nas leis mais rigor do que elas impõem" 7 .

Depois, tendo que ensinar, durante uma década, em Macau, resolvi estudar o sistema de poder nas colónias. Guiado por um artigo de Luís Filipe Thomaz 8 - que já pouco se cita, mas que foi uma síntese luminosamente pioneira -, trabalhei a hipótese de que, num ambiente ainda mais pluralista do que o do reino, estirado por forças centrífugas ainda mais potentes, alongado pelas distâncias - que não eram só de cruzar mares, mas também de vencer sertões -, onde essa mesma distância parecia fazer alongar a sombra do rei na sombra parasitamente engordada dos seus funcionários 9 . 0 meu material empírico era quase todo oriental, sobretudo macaense e algum goês; mas os testemunhos da literatura secundária apontavam invariavelmente num mesmo sentido. A centralidade "do Império" dissolvia-se num emaranhado de relações contraditórias entre uma multiplicidade de pólos, nos quais a coroa ocupava lugares e hierarquias diversas, frequentemente insignificantes, por vezes escandalosamente rebaixadas; e em que, em contrapartida, tanto se alevantavam poderes locais altaneiros, como as tais sombras dos "funcionários" régios se alongavam em dimensões autónomas, cobrindo e dando legitimidade prática a toda a sorte de iniciativas e ousadias, que os regimentos rejeitavam e as cartas régias mal podiam coonestar. Embora, por outro lado, se encontrassem nos discursos dos grandes estrategas - entre todos, nos de Afonso de Albuquerque - sinais muito visiveis de uma concepção de poder da coroa mais liberto, no quotidiano, de peias morais, mais livre de aproveitar as conjunturas, como recomendava Maquiavel. 0 qual, note-se, escreve 0 Principe, não para estados de equilíbrio político, mas para aqueles momentos dramáticos em que os 
10

Cf., sobre o tema, mas sem tocar este aspecto, ALBUQUERQUE, Martim de. A sombra de Maquiavel na étca tradicional português. Lisboa, Instituto Histórico, 1974.

\section{1}

HESPANHA, António Manuel. Panorama da história institucional e jurídica de Macau. Macau: Fundação Macau, 1995 (sintese em: Estruturas político administrativas do Império português. In: Outro mundo novo vimos. Catálogo. Lisboa: CNCDP, 2001).

\section{2}

Com muitos exemplos da mesma periferização do poder colonial, abrangendo o séc. XVIII, v., recente, LOPES, Maria de Jesus dos Mártires (coord.). O Imperio Oriental. 1660-1820. Tomo I, Lisboa: Estampa, 2006.

\section{3}

HESPANHA, António Manuel. Les autres raisons de la politique. L'économie de la grâce. In: SCHAUB, J.-F. (ed.). Recherches sur I'histoire de l'État dans le monde ibérique (15e.-20e. siècles). Paris: Presses de l'École Normale Supérieure, 1993.p.67-86; também em SCHIERA, Pierangelo (a cura di). Ragion di Stato e ragione dello Stato (secoli XV-XVII). Napoli: Istituto Italiano di Studi Filosofici, 1996.p.38-67. Note-se, de passagem, que a graça - que suscita no beneficiário a gratidão e o move a praticar um novo acto de graça a favor do primeiro benfeitor - é a mola tanto do serviço como da mercê. Daí que, se queremos descrever a lógica do todo, devemos falar numa lógica (economia, gramática) da graça e não da mercê. Ou seja, a economia da graça engloba tanto a economia do serviço como a economia da mercê. Já o contrário não se verifica; pelo que falar de economia da mercê é destacar um aspecto só de uma constelação incindivel (a graça, a gratidão, o serviço, a mercê), tornando as expressão, não apenas menos abrangente, como amputadora. Mas, como é evidente, isto é um detalhe, a que apenas me refiro pelas quase inúteis notas de rodapé que tem gerado. Mais importante é destacar que a lógica da mercê - a chamada cultura hervegetista - floresce tanto em culturas desmonetarizadas como em culturas de capitalismo nascente. Basta invocar a lição de Bartolomé Clavero, quando a liga à economia moral dos primeiros bancos (em CLAVERO, Bartolomé. Antidora. Antropolgia católica de la economia moderna. Milano: Giuffrè, 1991). Também eu utilizei este esquema conceitual para explicar o carácter endémico dos défices financeiros dos sujeitos políticos - coroas, grandes casas senhoriais) do periodo "corporativo" (0 cálculo financeiro no Antigo Regime. In: Actas do encontro ibérico sobre história do pensamento económico. Lisboa: CISEP, 1993; versión española, Cálculo finaciero y cultura contable en el Antiguo Régimen. In: PETIT, Carlos (ed.). Del ius mercatorum al derecho mercantil. Madrid: Marcial Pons, 1997. p. 91-108). principados estão em "revolução", a desfazer-se e a criar-se, em que a moral e a deontologia naturais se suspendem, até que tudo se aquiete num novo retorno à ordem, em que se feche o extraordinário 0 Príncipe e se reabra outra vez o ordinário De regimine principum. Daí que tenha na altura pensado que, se alguém quisesse encontrar a sombra de Maquiavel na ética politica portuguesa ${ }^{10}$, era nestes alvitristas ultramarinos que essa sombra se havia de encontrar, à maneira das sombra monstruosas que o poder da coroa projecta nas colónias distantes, extravagantes dos seus limites naturais, distorcendo a imagem daquilo que devia ser (da deontologia política).

Os estudos sobre Macau deram um livro 11, onde procurei descrever o sistema de poder colonial, especialmente referido ao império do Oriente, ilustrado com referências à armadura institucional de suporte. Foi este livro que inspirou o curto capítulo que se ocupa do Ultramar na História de Portugal - artigo cuja mesquinhez se deve ao facto de se contar, inicialmente, publicar um volume apenas para a Expansão, pelo que nenhum dos outros volumes se ocuparia do tema. 0 artigo foi, assim, um remendo, baseado num texto que, com Catarina Madeira Santos, preparara para um colóquio veneziano, onde o pude discutir com Anthony Pagden e com Adriano Prosperi ${ }^{12}$. Mas não passava, realmente de um esboço. Embora lá esteja o miolo do tema, com uma ressalva cuidadosa quanto ao Brasil, cuja situação eu então não estudara suficientemente e que então me parecia poder ser diferente, sobretudo pela contaminação do exemplo da colonização espanhola na América Central e do Sul. Lá chegaria, uns anos depois.

Entretanto, na Europa, a fortuna do modelo também beneficiaria muito, sobretudo dos trabalhos de Pedro Cardim e de Jean-Frédéric Schaub.

0 primeiro, num trabalho exaustivo sobre um tipo de fontes diferente das utilizadas por mim, reforçou poderosamente o argumento do carácter alternativo dos cânones do poder na sociedade de Antigo Regime, salientando como estes se alicerçavam sobretudo no condicionamento pelos sentimentos - dos sentimentos domésticos às virtudes da moral clássica e cristã -, transformados em deveres jurídicos pela estrutura absorvente e esponjosa do direito comum. Da piedade familiar surgiam os deveres e direitos jurídicos (dominica potestas) dos patresfamilias em relação aos seus familiares e dependentes, incluindo os escravos. Da gratia (ou liberalitas, caritas) surgia a mercê (ou beneficium), eventualmente o direito à mercê. Da misericórdia surgia o perdão, eventualmente o direito ao perdão. Da fraternitas (ou simplesmente da amicitia) surgia a compositio ou compromissum, eventualmente o dever de entrar em compromisso amigável, de resolver as questões per dimidiam (de cortar as diferenças pelo meio). É esta a economia moral - para usar a terminologia de E. P. Thompson - que Pedro Cardim reconstitui, num quadro geral que consome e ultrapassa de longe estudos meus e de Bartolomé Clavero sobre uma subregião singular deste mundo dos deveres estritamente não devidos ("antidorais") - a "graça" 13. Tudo está apenas in nube no meu livro, pelo que cabe totalmente ao meu Colega o mérito da sua extensa explicitação.

Jean-Frédéric Schaub continuou as Vésperas em duas direcções. A primeira foi a de aplicar muitos dos seus tópicos explicativos à análise de uma conjuntura - a da Restauração portuguesa de 1640, rejeitando uma explicação macro do acontecimento - a tradicional explicação da "revolta nacionalista" - e adoptando uma narrativa que traz para o proscénio os elementos micro das tensões entre grupos e redes de amigos e clientes, que se alinham em torno da prossecução de interesses particulares, tanto 
SCHAUB, Jean-Frédéric. La France espagnole: Les racines hispaniques de l'absolutisme français. Paris: Seuil, 2003.

\section{5}

Integrando reinos com constituições "pactadas", como a Catalunha ou, mesmo, Portugal, reinos com regimes forais, como as Vascongadas ou Txlalcala, no México, reinos com tribunais que se intitulavam de "soberanos", como acontecia com alguns conselhos palatinos dos dominios italianos, cidades com autonomia jurisdicional quase completa, que se dominavam "cabeças de reino", como Salvador, ou outras que se partiIhavam nas suas dependências entre dois impérios, como Macau.

\section{6}

Sobre alguma da literatura européia mais recente acerca dos modelos politicos prérevolucionarios, v. SOUZA, Laura de Mello e. O sol e a sombra: política e administração na América portuguesa do séc. XVIII. São Paulo: Companhia das Letras, 2006. p.52 ss.. Mas ainda: BENEDICTIS. Angela de. Una 'nuovissima' storia costituzionale tedesca. Recenti tematiche su stato e potere nella prima età moderna. Annali dell'Istituto italo-germanico in Trento, 16, 1990. p.265-301; SCHAUB, Jean-Frédéric. La penisola iberica nei secoli XVI e XVII: la questione dello Stato.Studi Storici, anno 36, gennaiomarzo 1995; ______. L'histoire politique sans l'état: mutations et reformulations. Historia a debate, III, Santiago de Compostela: 1993. p.217-235; _-_____. Le temps et l'État: vers un nouveau régime historiographique de l'ancien régime français.Quaderni fiorentini per la storia del pensiero giuridico moderno, 25, 1996. p.127-182; TORRE, Angelo.Percorsi della pratica. 1966-1995.Studi storici, 1995. p.799-829; BIZZOCHI, Roberto. Storia debile, storia forte. Storia, 1996. p.93-114.

\section{7}

HESPANHA, António Manuel. A constituição do Império português. Revisão de alguns enviesamentos correntes. HESPANHA, António Manuel. A Constituição do Império português. Revisão de alguns enviesamentos. In: FRAGOSO, João; BICALHO, Fernanda; GOUVÊA, Maria de Fátima O Antigo Regime nos trópicos. A dinâmica imperial portuguesa (séculos XVI-XVIII). Rio de Janeiro: Civilização Brasileira, 2001. p.163-188. A minha colega Laura de Mello e Souza deu-se ao trabalho de contar quantas vezes ai sou citado, atribuindo-me o honroso título de "campeão das referências"; apesar da substancial vantagem de ter ganho um lustroso capital simbólico, aproveito para declinar qualquer responsabilidade no facto e de pedir desculpa aos colegas preteridos, apesar autores de "chaves analíticas mais estruturais".

\section{8}

Estruturas politico administrativas do Império português. In: Outro mundo novo vimos. Catálogo, Lisboa: CNCDP, 2001; Porque é que foi portuguesa a expansão portuguesa?, comunicação apresentada ao Colóquio Internacional do Centro de História do Além Mar ("De um e de outro lado do Atlântico"), de 2 a 4 de Novembro de 2005, a publicar nas respectivas actas, bem como nas do encontro 0 Governo dos Povos. no sentido de próprios de um grupo como no de referidos a uma situação concreta. Salienta ao mesmo tempo a importância do argumentário jurídico e dos seus operadores - os juristas - no modelo corporativo de fazer politica. Como Schaub explica muito bem - e de forma insuspeita, porque não é jurista nem historiador do direito - a política faz-se tanto na corte como no tribunal; e, mesmo quando se faz na corte, faz-se segundo os cânones do direito: estribada em requerimentos, em papéis arrazoados ao estilo do direito, invocando direitos, usos e estilos, clamando pela Justiça.

Mas a contribuição mais importante de Schaub foi a de demonstrar a sorte que este modelo, que tinha sido estudado para uma monarquia ibérica, tinha tido, para além dos Pirenéus, naquele que é tradicionalmente considerado como o centro de um modelo oposto de governar - o modelo centralista e estadual, típico da monarquia borbónica francesa. Num livro escandaloso para a historiografia francesa ${ }^{14}$, Schaub revela como, afinal, o Sol começou por ser planeta de um sol ibérico, o dos Áustrias maiores, um sol político organizado segundo o modelo corporativo, particularista e, já agora, católico. Mas, ao mesmo tempo, como este modelo que aspirava ao domínio por uma só cabeça do mundo inteiro ("monarquia católica") era suficientemente dúctil para admitir, tanto parcerias diversas no governo da cabeça 15 , como formas múltiplas de reconhecimento das particularidades políticas locais e, assim, aspirar a um governo ecumênico que só era possivel na base desta flexibilidade das formas e modelos de domínio. Se os estudos de Schaub fossem prolongados por outras áreas dos governos europeus nos sécs. XVI a XVIII, creio que o âmbito geográfico do modelo corporativo se alargaria ainda. Creio que isso seria probabilissimo no mundo anglo-saxónico, onde a matriz jurídica é muito semelhante à do direito comum continental. E também já vai havendo bastantes sinais de que este modelo é aplicável às colónias da América latina e, até, a outras entidades políticas tradicionais ${ }^{16}$. Realmente, o que é difícil na história do mundo é encontrar Estados centralizados, não o contrário.

Em que medida é que este modelo é aplicável ao Brasil ?

A partir de uma curta comunicação apresentada no congresso anual da Society for Spanish and Portuguese Studies, realizado em Nova lorque, na primavera de 2000 (The constitution of Portuguese empire. Revision of current historiographical biases), levei a cabo leituras mais sistemáticas das fontes e literatura secundária relativas à administração colonial no Estado do Brasil. Fiquei, a partir de então com a convicção de que, afinal, o modelo corporativo de governo não apenas se adaptava perfeitamente ao que as fontes da época nos transmitiam, como era indispensável para remover algumas distorções muito difundidas na história colonial brasileira, na sua narrativa das relações entre a metrópole e a colónia e na das origem e eclosão do movimento independentista. Expus as minhas primeiras conclusões num volume colectivo que tem sido lido como integrado nesta mesma inspiração ${ }^{17}$, tendo desenvolvido esse meu texto em comunicações sucessivas ${ }^{18}$.

Para mim, as conclusões que tirava para o Brasil nada tinham de surpreendente ou de extraordinário, se exceptuarmos que não se verificara aí uma antes suspeitada influência do modelo espanhol de domínio colonial, o qual também se tem vindo a verificar não ser, nem de longe, tão centralista como se dissera. De facto, se o policentrismo, o pluralismo jurídico-político, a confusão jurisdicional, a raquítica extensão do domínio periférico da coroa, se verificavam no Reino, um pedacinho territorial de $89000 \mathrm{~km}^{2}$, territorial e linguisticamente integrado desde o séc. XIII, como é que isto podia deixar de 
Poder e administração no Império Português, Modos de Governar/Projeto Temático/ Cátedra Jaime Cortesão, Paraty, 2005; Porque é que existe e em que é que consiste um direito colonial brasileiro?, comunicação ao Encontro Brasil-Portugal: sociedades, culturas e formas de governar no Mundo Português - sécs. XVI a XVIII, Departamento de História e Linha de Pesquisa História Social da Cultura/PPGHIS, IFMG, Belo Horizonte; publicada em FURTADO, Júnia Ferreira et alii. ________. São Paulo: Annablume, 2006; a ser também publicada em Quaderni fiorentini per la Storia del pensiero giuridico moderno, 2006. Para um balanço do tema, cf., também, CARDIM, Pedro. 0 governo e a administração do Brasil sob os Habsburgo e os primeiros Bragança. Hispania. Revista del Consejo Superior de Investigaciones Cientificas. Madrid: vol. LXIV/i, n. 216 (Enero-Abril 2004), p. 117-156. pp 117, Enero-Abril, 2004

\section{9}

Ver artigos citados nas notas anteriores e muitas fontes e bibliografia ai citadas.

\section{0}

Sobre esta historiografia, v., ultimamente, SOUZA, Laura de Mello e. 0 sol e a sombra: política e administração na América portuguesa do séc. XVIII. São Paulo: Companhia das Letras, 2006. maxime 27-40. Sobre um idêntico sentido na historiografia estrangeira dedicada ao Brasil, v. p.41 ss..

\section{1}

Por isso eu mesmo entendo o empenho em manter vivo este legado, feito de "tradições a considerar", não decerto - digo eu ... - por serem tradições, mas antes por conterem - se e quando contiverem - sabedoria e acerto.

\section{2}

Cf. testemunhos em MELO, Evaldo Cabral de. Um imenso Portugal - história e historiografia. São Paulo: Ed. 34, 2002. Claro que este tópico de "um imenso Portugal", glosado ironicamente por Chico Buarque, nunca se realizou nem podia realizar, ficando como um tópico ideológico que o salazarismo usou até ao enjoo, e a que Gilberto Freyre deu alguma caução, ainda que salientando com grande saber e eloquência, a especifidade desse (palavras dele ...) "mundo que o português criou".

23

Cf. indicações de interpretações históricas neste sentido de que a diferença colonial era procurada.

\section{4}

Sobre os programas políticos, urbanísticos e decorativos de Nassau, no Brasil e na Europa, v. o belo livro de MELO, Evaldo Cabral de.Maurício de Nassau. São Paulo: Companhia das Letras, 2006.

25

Sendo por isso que se criou, em certos círculos intelectuais brasileiros, a idéia de que o Brasil teria ganho mais com a colonização projectada, metodicamente aplicada, rigorosa, austera e proto-racionalista, do que com a improvisada e descuidada colonização portuguesa. acontecer num imenso território, cujas costas estavam separadas da metrópole por mais de um mês de Oceano a atravessar, cujos interiores eram, para além disso, muito pouco acessíveis a partir da costa, um território enorme, dividido por sertões, por rios, por florestas, por nativos pouco dómitos, por colonos ainda mais indómitos e senhores de si, habituados à vida política de um "território de fronteira" ? De resto, a leitura das fontes, oficias ou particulares, juridicas ou literárias, intencionais ou obiter dicta, era esmagadoramente consistente na imagem transmitida: uma sociedade que se habituara a viver sobre si, onde bandos e partidos faziam a lei, ao mesmo tempo que sofriam mal a lei do rei ou a da Igreja, que usavam da chicana judicial para enrodilharem as situações inconvenientes, quando não as deslindavam de formas mais brutalmente expeditas, em que as autoridades nem eram normalmente obedecidas nem sustentadamente reverenciadas, em que estas mesmas participavam no estilo local de vida, usurpando-se mutuamente as jurisdições, parasitando com pouca subtileza a jurisdição real que representavam, envolvendo-se em querelas judiciais intermináveis, cruzando agentes nas viagens à corte, onde buscavam favores nos diversos lugares a que se reportava a administração ultramarina, ligando-se de muitos modos a interesses locais. As descrições deste tipo são tão abundantes e tão repetitivas - variando apenas interminável o rol das peculiaridades locais - que nem paga a pena transcrever aqui exemplos 19.

A versão que dou nesses artigos não tem nada de novo. Os melhores intérpretes da realidade histórica do Brasil colonial não dizem outra coisa. Com rarissimas excepções, todos identificam o "sentido" da colonização portuguesa do Brasil com uma enorme falta de domínio do centro sobre a periferia, lamentando-a uns, como sinal de confusão e de irracionalidade, congratulando-se outros com ela, como sinal da vitalidade própria da sociedade brasileira 20 . Mas todos aportando intuições fundadas no seu profundo e meditado trabalho das fontes e da realidade do Brasil, a qual, tal como a portuguesa, manteve esses traços corporativos e fortemente localistas até praticamente aos nossos dias 21.

$E$, realmente, porque é que os portugueses haviam de ter como desígnio construir, no Brasil, uma sociedade diferente daquela que eles conheciam e em que viviam. Eu creio que havia muito quem quisesse, na altura, fazer do Brasil, "um outro Portugal", como então mais do que um escreveram 22. É certo que muitos, mesmo muitos destes partidários da clonagem lusa, estavam - há imensos testemunhos disso e, de resto, a teoria social da época explicava-o claramente - conscientes de que os climas, o meio físico e a distância haviam de tornar diferente as sociedades tropicais. Mas isso não era algo de procurado - nomeadamente como forma de facilitar a exploração 23 -, mas antes algo que tinha que ser sofrido, como pertencente à natureza das coisas. A colonização européia foi, toda ela, euro-cêntrica; isso estava implícito quer no conceito de evangelizar, como no de civilizar. Para não sair do Brasil, confronte-se o modelo jurídico-legal da colonização holandesa. Também aí, como nos programas urbanísticos e decorativos de Maurício de Nassau, nos deparamos com um projecto mimético em relação à sociedade neerlandesa e norte-alemã, em que os elementos nativos constituem, não o eixo da representação, mas os detalhes exóticos que testemunha a grandeza do domínio da Europa $24 \mathrm{e}$ em que o propósito centralizador, nos aspectos administrativos e económico-financeiros, eram ainda mais vincados do que os da colónia portuguesa ${ }^{25}$. Atente-se apenas na constituição dos órgãos de governo, mesmo 


\section{6}

Sobre a colonização holandesa em Pernambuco: crónica da época, SALVADOR, Manuel Calado do. $O$ valeroso Lucideno on triunfo da liberdade. Lisboa: 1648; fontes para a história administrativa, Revista trimestral do Instituto HistoricoGeograhico e Etnographico do Brazil, Tomo 49, $2^{\circ}$ vol., 1886.MELLO, José António Gonsalves de(ed.). Fontes para a história do Brasil holandês. Recife: 2 vols., 1981 e 1985; monografias principais (para além da vasta e conceituada obra de Evaldo Cabral de Melo), MELLO, José António Gonsalves de. Tempo dos flamengos. Influência da ocupação holandesa na vida e na cultura do Norte do Brasil. Rio de Janeiro: 1947; BOXER, Charles Ralph. Os holandeses no Brasil. Pemambuco: 2004.

\section{7}

Sobre esta historiografia, v., ultimamente, SOUZA, Laura de Mello e. $O$ sol e a sombra: politica e administração na América portuguesa do séc. XVIII. São Paulo: Companhia das Letras, 2006. maxime 27-48.

\section{8}

Veja-se, como a melhor sintese, o completo e extenso artigo de GALLO, Alberto.La venalidad de oficios publicos en Brasil durante el siglo XVIII.In: BELLINGERI, Marco. Dinamicas de Antiguo Régimen y orden constitucional [...]. Torino: Otto Editore, 2000.

29

SOUZA, Laura de Mello e. Op. cit, 48 ss.. municipal, reservados a holandeses (ou seja, "reinóis") e de religião reformada. Claro que, também aqui, o projecto de "uma nova Holanda" teve que se adaptar, tanto às condições mesológicas, como à existência de uma vasta colónia luso-brasileira, com a qual rapidamente se teceram laços de convivialidade e de interdependência. E o resultado voltou a ser essa amálgama intrincada de poderes da sociedade corporativa, apesar de tudo mais bem suportada pelo direito comum clássico da Europa centro-meridional do que pelo mais estrito Roman-dutch law 26.

Entre os estrangeiros não portugueses 27 há material de sobra para corroborar o carácter centrífugo e localista do sistema político português, também nas colónias. Poderia desenvolver muitíssimo este ponto, recorrendo a nomes tão prestigiados como Charles R. Boxer, John Russel-Wood, Stuart Schwartz e outros. Mas, já que me estou a referir ao insuspeito texto de Laura de Mello e Souza, tomo-o como testemunho. Pois nele se pode ler que Charles Boxer afirma que "A Câmara e a Misericórdia podem ser descritos, com algum exagero, como os pilares gémeos da sociedade colonial portuguesa do Maranhão até Macau. Elas garantiam uma continuidade que os governadores, os bispos e os magistrados transitórios não podiam assegurar [...]" (cit. p. 42). Ou que John Russel-Wood insiste "no carácter sistémico da descentralização administrativa e [n]as numerosas atribuições e responsabilidades do "homem no local»" (cit. p. 45). Ou que o português Francisco Bethencourt aponta, no estudo do oficialato local, para o efeito periferizante da venalidade dos cargos, ainda que com uma dimensão que Laura de Mello e Souza parece considerar, e muito bem, ainda insuficientemente valorizado (cit. p. 46) 28 .

Nem por isso a inspiração interpretativa que o livro abriu tem estado, no Brasil, isenta de críticas, por vezes pesadas, e vindas de historiadores brasileiros de peso. Isto não apenas é natural como me estimula muito, obrigando-me a pensar e rever coisas ditas, tanto quanto à sua pertinência ao mundo colonial, como quanto ao seu rigor no próprio cenário original do livro. Gostava de deixar aqui apontado um apanhado dessas críticas e revisitações minhas, quer como um caveat dirigido ao leitor, quer como uma homenagem a uma historiadora e uma colega estimada de há muito, que ultimamente me prestigiou com uma análise desmerecidamente alongada e pointilleuse dos meus pontos de vista. Refiro-me a Laura Mello e Souza, no artigo introdutório ao seu último livro 0 Sol e a sombra ${ }^{29}$.

A primeira crítica que se dirige ao meu estudo - o seu "calcanhar de Aquiles" - seria "a pouca atenção dada à especificidade dos diferentes contextos imperiais - ou mesmo "o descuido quanto aos contextos imperiais" (p. 48). Esta crítica suscita duas linhas de contra-argumentação. Uma delas é a de referir que, nas menos de 100 pp. que até hoje dediquei ao sistema politico corporativo no "Império" não pretendi fazer um levantamento exaustivo das miriades de situações aí existentes; mas lembro-me de ilustrar a minha linha geral de argumentação com exemplos tirados de Timor, Macau, Malaca, Goa, Ormuz, Moçambique, Angola, Pernambuco, São Paulo, Minas Gerais. E li o suficiente para saber que não teria que rebuscar absolutamente nada, nem de desbancar estantes de arquivos para encontrar milhares de exemplos de afirmação de poderes locais, de incumprimentos de ordens metropolitanas, de instituições localmente criadas, de conflitos insanáveis de jurisdições, de atropelos e de desaforos, de poderosas coligações vitoriosas de interesses coloniais. A segunda consideração é mais fundamental, segundo creio. A periferização do poder e o localismo ou carácter contextual das 
30

Cf., pp.48-49: "jurisdicionalismo", "governo polisinodal", "processo com garantia de contraditório"; limitação dos poderes da coroa, confusão jurisdicional e consequente atonia administrativa.

31

Ou, como diz, muito bem, Laura de Mello e Souza, "um elemento constitutivo e característico" deste sistema (p. 48)

32

Cf., com alguma justeza, p.51-52.

\section{3}

V., justamente para o Brasil e para Portugal, SEELANDER, Airton. Polizei, Ökonomie und Gesetzgebungslehre, Frankfurt am Main, Vittorio Klostermann, 2003; ___________A polícia e o rei-legislador: notas sobre algumas tendências da legislação portuguesa no antigo regime. In: BITTAR, Eduardo C. , (org). História do direito brasileiro: leituras da ordem juridica nacional. São Paulo: Atlas, 2003; e ainda, sobre um ponto mais particular, NEDER, Gizlene. Iluminismo jurídico-penal brasileiro. Obediência e submissão. Rio de Janeiro: Freitas Bastos Ed., 2000.

\section{4}

Dos melhores trabalhos sobre este periodo

"reformista" é a tese, ainda inédita, de Catarina Madeira Santos sobre os projectos de reforma iluminista para Angola (Um governo polido para Angola. Reconfigurar dispositivos de domínio, defendida em Dezembro de 2005, na Faculdade de Ciências Sociais e Humanas da Univ. Nova de Lisboa).

\section{5}

Cf. CLAVERO, Bartolomé. Hispanus fiscus, persona ficta: concepción del sujeto politico en el ius commune moderno. Quaderni Fiorentini per la storia del pensiero giuridico moderno, 11-12, p.95-167, 1982-83.

\section{6}

Em contrapartida - e com o respeito e amizade que me ligam a eles - já me parece que as novidades que Nuno G. Monteiro e Mafalda Soares da Cunha identificaram nas carreiras ultramarinas de governadores do ultramar não têm nada a ver, segundo creio, com a questão que se discute, que é a da extensibilidade ou não ao ultramar de paradigmas gerais de governo e da sua cronologia (cf. p.49). Eles tratam de um outro assunto - também muito importante -, que é basicamente o do sentido percursos ultramarinos - e, naturalmente, da sua caracterização quantitativa e tipológica - na carreira da nobreza e alta nobreza de Portugal. Boa história, mas é outra estória .. configurações políticas, bem como outras características que estão muito correctamente listadas no texto que estou a comentar 30 são, como já disse, uma característica sistémica do sistema político corporativo ${ }^{31}$, gerada pela abertura do direito de então às normas locais da vida social. Isto sabemo-lo a partir da própria doutrina política e jurídica, lendo as suas fontes (coisa que, em contraste com a minha natureza de parvenu ao mundo colonial ${ }^{32}$, faço continuamente há várias décadas). Dai que, tal como os astrónomos fizeram com o agora malogrado Plutão, possamos prever todas estas caracteristicas sempre que haja uma base empírica que torne altamente provável a gestação de um sistema político deste tipo. Só que, no caso concreto, a comprovação empirica está aí à mão. Cada manifestação de uma nova adaptação contextual ainda reforça a validade do modelo, mostrando como ele é capaz - ao contrário dos modelos políticos universalistas que virão depois - de incorporar os localismos e reverberar as diferenças.

Ao contrário, dizia eu, dos modelos universalistas que virão depois ... Como expliquei num dos capitulos das Vésperas [...], o sistema corporativo soçobra face ao geometrismo do racionalismo setecentista, com algumas raizes teóricas ainda anteriores. A partir de então, paulatinamente e segundo perfis cronológicos variáveis, vai-se implantando a ideia de que o bom governo obedecia a máximas racionais e universais, que decorriam da natureza racional dos consócios, mas que convinha que o centro político impusesse de uma forma racionalmente despótica. Daí que eu sempre tenha repetido que, a partir da segunda metade do séc. XVIII, muito pode começar a mudar, desde logo um novo e central lugar das ideias de "disciplina" e de "boa polícia" (a gute Policey alemã, que os franceses rapidamente adoptam sob a etiqueta de "science de la police", como sinónimo de arte de organizar disciplinadamente a polis segundo modelos científicos tendencialmente universais). Só que isto chega tarde a Portugal e aos seus domínios 33 ; se não me engano (e, francamente, acho que não me engano e que, portanto, não há por aqui grandes "problemas a contornar"), é mesmo só com Pombal e com os ministros ilustrados de D. Maria que planos particulares e gerais de uma organização política do Ultramar ganham forma, primeiro em relatórios, consultas e directórios, depois em projectos concretos de reformas territoriais, económicas, urbanísticas e de governo, que visam vários pontos e situações do império, desde Macau ao Brasil, passando por Angola ${ }^{34}$. Antes, há alguns assomos disciplinadores; como Laura de Mello e Souza descreve, sobretudo no domínio da fazenda. 0 que não me espanta nada, não apenas pela excitação (mesmo reformista) que o cheirinho do vil metal sempre causa, mas também porque se tratava de um domínio que sempre escapou ao espartilho jurisdicionalista, de acordo com a própria doutrina corporativa. A fazenda era a gestão da casa de el-rei, fazia parte do seu domínio doméstico, os seus funcionários não eram sequer "des vraies officiers de la République (como escreve Jean Bodin)", dominando aí 0 rei como um paterfamilias de poderes (domésticos) indisputados 35 . Por uma coisa e por outra, a fazenda foi sempre o alfobre das novidades das monarquias corporativas e, também, o campo de eleição dos negregados alvitristas, de arbitrio (vs. razão) sempre pronto a inventar novos meios de fazer crescer a riqueza do rei, mesmo com o risco de criarem esse monstro da deontologia régia, que era um rei rico feito à custa da pobreza dos súbditos ${ }^{36}$. Daí que, para quem se ocupe de temas muito estreitamente relacionados com a fazenda - como a mineração e a cobrança dos direitos reais dos quintos, ou de regiões mineiras em que estes eram os problemas centrais - o séc. XVIII já apareça como um período de aperto do controlo; embora, os historiadores 
37

Nomeadamente no domínio da justiça, sempre feita "em nome de El-rei, por muito contrária que fosse ao seu direito; sobre a justiça, num sentido que não me parece destoar do que aqui insinuo, v., como do mais recente e mais interessante, LARA, Silvia Hunold; MENDONÇA, Joseli Maria Nunes. Direitos e Justiça no Brasil. Campinas: Editora Unicamp, 2006. As duas autoras pertencem a um ramo da historiografia que estuda a equivocidade do direito, mesmo da lei: e, logo, as virtualidades de um seu uso "alternativo", jogando a favor dos dominados. Também neste sentido se poderia falar de uma "periferização do direito".

38

Cf. SOUZA, Laura de Mello e. 0 sol e a sombra: política e administração na América portuguesa do séc. XVIII. São Paulo: Companhia das Letras, 2006. p.51 ss.. dessa época - como, antes de todos, Laura de Mello e Souza e Júnia F. Furtado - também saibam, que este controlo era quase sistematicamente aniquilado por mil e uma formas de fuga, que, "de tão subtis e tão peritas, mal podem sequer ser bem descritas " (para citar um belo verso de Sophia de Mello Breyner).

A questão central - que arranca do próprio título da já citada colectânea $O$ Antigo Regime nos Trópicos [...] e que constitui a espinha dorsal das vigorosas reticências de Laura de Melo e Souza - é, porém, outra, e esta, de facto, central: o Antigo Regime poderá existir "nos trópicos"? Ou seja, substituindo a referência geográfica por uma referência política, Antigo Regime e Regime Colonial podem coexistir?

Dou de barato que a expressão Antigo Regime é, pelo menos equivoca e, com isso, dispenso-me de analisar toda a argumentação sobre o sentido de "Antigo Regime" desenvolvida de pp. 63 a 67. Realmente, eu nem uso essa designação nos títulos dos meus textos, embora talvez a tenha utilizado, com um sentido meu próprio, porventura pouco ortodoxo. Tão pouco me detenho muito na questão "das distâncias", o tal "descuido" (p. 50) que me leva a meter no mesmo saco o longínquo Macau e os próximos Rio ou Salvador. As distâncias a que me refiro são as que determina a acessibilidade geográficas ou simbólicas e não as que medem os compassos ou os relógios. E essas podem ser maiores para o interior de um serão do que para uma longa viagem por mar. De resto, o que eu digo e ai se cita é que "os governadores ultramarinos estavam isolados da fonte do poder por viagens que chegavam a levar anos" (p. 50).

Vou antes ao miolo do argumentário.

A primeira impossibilidade da minha tese é um bocado "armadilhada". Soa assim (p. 51). Eu, que insisto tanto num sistema alternativo de poder, onde este se exercia de forma "doce" e quase puramente simbólica, pelo reconhecimento de um soberano e de uma pátria comum, quando me encontro com ele, no ultramar, acho tão diáfano que nem o vejo, negando que exista e fixando-me apenas na visibilidade dos poderes locais. Ora, respondem-me, "claro que o Estado existe; e existe precisamente como tu achas que devia existir, ou seja frágil e dominado pelos «nichos locais onde o poder se constrói»; só que, entretanto, quando o encontraste aqui, assim mesquinho e fraco, tu caíste na tua própria armadilha, esquecendo-te que Ihe tinhas retirado quase todo o poder institucional e não reconhecendo nele aquilo que afinal the deixaste, uma mera cobertura simbólica".

Se não me engano, eu não digo que o "Estado" (valha a simplificação) colonial não exista. Sim, existe, nas colónias e no reino, como eu tenho defendido que ele era. E manifestava-se também nisso de que, muito disciplinadamente, todos tripudiavam e faziam tropelias "em nome d'el-rei", guiados pelo amor que tinham à coroa e ao seu rei. E a própria coroa, em estado de necessidade e em transe de perder até a face, frequentemente cobria os desmandos, ou com o silêncio de presumida ignorância, ou com o manto do perdão ou mesmo com o alarde de uma mercê por tais serviços. Pode, realmente, dizer-se que o modo de governar do "Estado moderno" era este, o de se deixar invocar ${ }^{37}$; e que exigir-lhe um poder mais efectivo não passa de uma retroprojecção da imagem que mais tarde se formou do Estado, nomeadamente desse Estado distante, exigente e dominador, que é o "Estado com colónias" (ou o "Estado nas colónias") 38. Para mim, isto não é armadilha nenhuma, antes corresponde ao ponto de fuga, à linha de tendência, do que defendo como sendo a natureza sistémica das monarquias 
39

Jean Bodin escrevia, em 1577, que "d'autant que la puissance souveraine est moindre, reservées les vraies marques de la majesté, d'autant elle est plus absolue". Porém, o que ele aqui diz, não se refere a uma concepção minimalista e puramente simbólica de Estado (até porque há a reserva das tais "vraies marques de la majesté", que não são poucas), mas ao poder conformativo e disciplinador do segredo, bem como ao uso político da dissimulação, que torna útil esconder o poder, quando este corre riscos de ser desfeiteado. Todos conhecemos, ainda hoje, as vantagens desse uso económico e reservado do poder.

40

HESPANHA, Antônio Manuel. Luís de Molina e a escravização dos negros. Análise Social. 157, p.937-990, 2001

41

Cf. a identidade do radical latino de familia e de famulus. corporativas, tão bem expressa na lista dos poderes do rei que, vinda do direito lombardo, se pode ler no título II, 26 ("Dos direitos reais") das Ordenações filipinas ${ }^{39}$. Para quem este osso é duro de roer é para quem vê no dito "Estado com colónias" um Leviathan nos trópicos, poderoso, mandão, predador, rapace. Só que isto é dificilmente suportado por essa enumeração dos "direitos reais" a que acabei de me referir, decorrendo antes daquilo que a teoria política mais moderna (oitocentista) do Estado e da colonização colocou como conteúdo corrente das palavras "Estado" e "colonização". Em suma, para mim uns trópicos sem Leviathan não me aborrece mais do que um Leviathan sem trópicos; não sei, porém, se não perturbará um tanto a imagem tradicional de um "Império colonial" ... como Deus mandava.

A segunda questão substanciosa quanto à incompatibilidade entre "Antigo Regime" (perdoe-se-me a facilidade de expressão ...) e "Sistema colonial" relaciona-se com o facto de a América portuguesa se ter "assentado na escravidão" (ibid., p. 56). Eis um ponto em que entro com pouco à vontade, de tal modo me parece central na compreensão da sociedade brasileira, colonial e pós-colonial. Sendo ainda certo que se trata de uma questão multifacetada e complexa, como o prova a turbulência da sua historiografia, traço para o qual Laura de Melo e Souza chama, de resto, a atenção (p. 61). Acresce que, aí decisivamente sim, sou tudo menos um especialista. Em todo o caso, sempre exporei algumas perplexidades sobre esta alegada incompatibilidade entre o sistema corporativo e o sistema esclavagista (ou escravocrata, como se diz no Brasil).

Em primeiro lugar, todo o tesouro de imagens e de conceitos que permitiu justificar e sustentar ideologicamente a escravidão tem uma indubitável origem européia. A escravidão é uma figura do direito romano, por este detidamente regulada, regulação que foi a única matriz jurídica disponivel, naturalmente reelaborada por juristas europeus, quase todos ibéricos, dos quais destaco o luso-espanhol Luis de Molina, cuja doutrina relativa aos escravos já foi objecto de um artigo meu 40 . Antes disso, a escravatura fora objecto de reflexões antropológicas e filosóficas de Aristóteles, que a filosofia, a ética e a política europeias incorporaram e as leis copiaram. Por cima disto, o sistema corporativo construíra toda uma moldura de autonomia jurídica e governativa da "casa", da qual os escravos faziam parte, juntamente com outros membros da família ${ }^{41}$. Para a sociedade corporativa, os escravos eram um elemento da casa, da família, e não, a bem dizer, um elemento da polis, da respublica, do Estado, o qual Jean Bodin define como "uma respublica de famílias". Ou seja, do ponto de vista da mundividência corporativa, o escravo, ou mesmo uma multidão de escravos, não constituía um elemento dissonante da comunidade, que obrigasse a reconfigurar o seu desenho, a sua teoria, o seu direito. $E_{1}$ de facto, não conheço nem tratados de ética, nem códigos, nem leis substanciais, que lidem com o problema da escravidão massiva no Brasil. Aparentemente, o que viera da Europa, chegava. Apesar de tudo, pergunto humildemente, há alguma construção doutrinal especifica, alternativa, no Brasil de Antigo Regime, sobre a questão da escravidão? tudo isto, dir-se-á, passa-se no tal domínio que me magnetiza e me faz esquecer o real, a pratica, a questão politica do governo dos escravos. Mas, volto a ousar exprimir uma sensação. 0 governo dos escravos não foi sempre - pelo menos no período colonial, porque, depois, as coisas agudizam-se, requerendo outra panóplia de medidas - uma questão essencialmente doméstica ? Uma questão que a sociedade civil resolvia entre si, o mais das vezes fora de qualquer enquadramento legal e sem qualquer recurso às forças oficiais ? Claro que meirinhos e autoridades colabo- 
42

Cf. SOUZA, Laura de Mello e. 0 sol e a sombra: política e administração na América portuguesa do séc. XVIII. São Paulo: Companhia das Letras, 2006. p.57.

\section{3}

Mas na Europa, pelo menos, estas classificações eram visibilizadas pelo estatuto jurídico, pelos trajos e, quando a Europa se expandiu pelo resto do mundo, até pelas feições, pela língua e, principalmente, pela cor da pele. 0 que, para a análise historiográfica, política e sociológica, não deixa de clarificar muito as coisas. Na sociedade colonial brasileira estas expressões são de uma opacidade completa, pois a porosidade das duas categorias era enorme. Uma geração - ou mesmo menos - transformava um reinol num colono, confundindo frequente uns e outros em colonizadores de terceiros, de que muitas vezes não se fala - escravos e ameríndios.

\section{4}

HESPANHA, António Manuel. Savants et rustiques. La violence douce de la raison juridique. Ius commune. Frankfurt/Main, 10, p.1-48, 1983.; recensão: Révue d'histoire du droit, 1984 (A.-J. Arnaud); versão portuguesa, Revista critica de Ciências Sociais, 25/26, p.31-60, 1988.

Recebido para publicação em Janeiro 2007.

Aprovado em Fevereiro de 2007 ravam na perseguição e busca de escravos fujões ou quilombolas, ajudavam na destruição de um ou outro quilombo. Claro que, em última instância, lá estava o direito a afirmar os poderes dos senhores de escravos. Mas estes precisavam de um recurso sistemático a estes meios para manter o sistema ? Por exemplo, era frequente o recurso aos tribunais, no Brasil colonial, para reconduzir os escravos à sua condição? Mais do que isto: não será certo que o direito e as leis enleavam, mais do que agilizavam, os "poderes naturais" dos senhores de escravos ? Que estes não gostavam mesmo nada que um juiz ou um corregedor viesse meter o nariz na senzala, para ver se as normas jurídicas que proibiam certos tratos ou abusos eram efectivamente cumpridas? Talvez eu esteja enganado. Mas, então, é preciso que se me indiquem as fontes de onde constem as tais intervenções quotidianas de um Estado repressor dos escravos insubordinados. Sem que existam estas provas, diferenciadoras em relação à rara intervenção europeia do Estado contra os seus escravos do interior", terei que concluir que, afinal, "administrar uma sociedade composta predominantemente por brancos" era pouco diferente "que fazê-lo quando o contingente escravo podia chegar - como chegava em algumas regiões - a 50\% da população" 42. Repare-se que falo de acção do Estado e não da "sociedade civil", nas suas múltiplas formas de organização, desde a doméstica até à eclesiástica, passando homens de mão e matadores a soldo dos notáveis ou pela cooperação dos próprios "escravos leais". Não se trata, por outras palavras, que a escravidão gerasse problemas de governo; trata-se de saber quem os resolvia, e como.

No fundo, os escravos estavam, para as sociedades coloniais, como criados, aprendizes, moços e moças de lavoura, rústicos ou camponeses, para as sociedades europeias. Milhões de pessoas, praticamente desprovidas de direitos, à mercê dos pais de família. Não nos esqueçamos que o direito comum, o direito romano, a potestas domestica e todo o sistema repressivo de sociedades com pouco Estado vigoravam mesmo nos Estados do Leste alemão, na Polónia e em certas zonas da Rússia, em que a servidão perdurou até ao liberalismo. Sem incompatibilidades de princípio. Deve aí ter havido mais progroms contra os judeus organizados pelos soberanos do que operações oficiais "de pacificação" de servos e camponeses.

Do que acabo de escrever já se deduz que continuo a pensar que a chave interpretativa que este livro fornece pode servir a historiografia brasileira, sem sequer obrigar - o que seria grave - à ocultação da violência colonial. Ou, dito de outra forma, sem sequer impedir a consideração da diferença entre (uma entidade indefinida a que alguns historiadores chamam) "colonos" (i.e., colonizados, vítimas da colonização) e (outra a que os mesmos chamam) "reinóis" (i.e., colonizadores, agentes e beneficiários da colonização). Realmente, houve uma coisa e outra; como, na Europa, houve senhores e camponeses ${ }^{43}$. Mas, apesar das tensões, desigualdades e espoliação entre uns e outros, eles conviveram, uns e outros, nessa sociedade hierarquizada, fundada na desigualdade e no privilégio, internamente dominadora e marginalizadora, que foi a sociedade corporativa; no seio da qual uns exploraram tranquilamente os outros, os segregaram e dominaram, os silenciaram e gozaram com o seu silêncio ${ }^{44}$. Nos quadros e com os instrumentos que a matriz ideológica e institucional da sociedade tradicional europeia abundantemente dispunha. 